\title{
MAPPING HUMAN DIGNITY IN THE NEW TESTAMENT: CONCERNS, CONSIDERATIONS AND CONCEPTS ${ }^{1}$
}

\author{
Jeremy Punt \\ Old and New Testament \\ Stellenbosch University
}

\begin{abstract}
Enquiring about hermeneutical and methodological considerations appropriate to studies on the modern concept of 'human dignity' in the New Testament, some initial concerns are raised about the potential benefit of such work. Investigations of human dignity in the New Testament secondly requires appreciation for the complex and multi-facetted way in which first-century people and their value or worth or dignity were in play; for accounting for first-century CE considerations or contexts, where honour and shame were pivotal values within a hierarchical and patriarchal society of limited good; and, for an environment that was thoroughly saturated with the omnipresent and hugely influential Roman Empire on socio-political, as well as economical and religious levels. Thirdly, a range of concepts, themes and topics found in the New Testament - some of which are invoked in theological discussions on human dignity, but others whose potential in this regard has perhaps not been adequately recognised - are briefly identified and considered for their possible contribution to conceptualising human dignity in biblical and theological discourse.
\end{abstract}

Key Words: Human Dignity, Social Location, Roman Empire, Incarnation, New Testament Anthropology

\section{Introduction}

Human dignity as concept in the New Testament, as elsewhere, is construed, complex and multi-variable, and at best of times avoids all-inclusive definitions or exhaustive description. Reasons for such complexities are various and multiple, but are both necessary for and worthy of consideration in any attempt to circumscribe human dignity in the New Testament. Two early, prominent concerns stand out, one historical and the other linguistic. First, the social fibre of communities in the first-century CE Mediterranean world ${ }^{2}$ differed considerably from our modern context, within a socio-political climate thoroughly determined at all levels of life $^{3}$ by the Roman Empire - issues that will be addressed in the second section of this contribution. Secondly, the linguistic turn of the twentieth century has

Paper read at an Old \& New Testament day seminar on "Human Dignity in the Bible", Stellenbosch, 28 October 2009.

2 In the $1^{\text {st }}$ century $\mathrm{CE}$ socio-cultural environment the pivotal values of honour and shame largely regulated behaviour within the reigning hierarchical and patriarchal society, characterised by collectivism and the notion of limited good, socially transacted through an elaborate patronage system.

3 Such levels included the military (the Roman legions and the local figureheads); economic (agricultural, trade and industry and business relations, taxes, etc.); administrative (local officials, patron-client relationships, etc.); and, religious levels (emperor-cult, etc.) - levels that in hindsight can be distinguished but which at the time were seamlessly tied into the greater web of relations that constituted first-century reality. 
alerted us to our indirect, mediated and heterogeneous relationship to the world, ancient and modern, and for the central role of language in all of this (Lategan 1989:105-116), underlined by the New Testament authors' investment in metaphorical language. ${ }^{4}$

The hegemonic, hierarchical, slaveholding societies of the first-century of course did not know of the contemporary ideas about human dignity defined in terms of freedom, equality and fraternity, the modern notion of the dignity of all people regardless of race, class, creed, orientation and so on. But, considering the relationship between the considered value of human beings and the texts of the New Testament requires more than reading these texts within and as part of their appropriate socio-historical context of the distant past. ${ }^{5}$ Today's notions about human dignity should also be understood in the aftermath and context of, and in reaction to, the more recent centuries of world history characterised by enslavement, war and violence, inequality and oppression. As broad historical frame within which the unassailability and sacredness of all human life has been formulated, the biblical texts (and Christian tradition) were, especially in the last century, increasingly employed in support of human dignity and rights in the Western world. Given the concerns addressed at this seminar, my paper will, however, focus on the former aspect, in an attempt to trace possible parameters for using the New Testament in the discussion on human dignity. ${ }^{6}$

\section{Concerns: Dignity, In-dignity, or Renounced Dignity?}

To talk in short-hand fashion of 'human dignity' in the New Testament and its world, is of course to talk of a derived and in every single instance a qualified value - not presented in the New Testament an inherent characteristic of all human beings without exception. In other words, in the New Testament human dignity is a construed or constructed rather than a discovered or an essentialist concept. Key moments or departure points for thinking about the value of human existence according to the New Testament would probably include aspects as wide-ranging as the incarnation of Jesus as human being, even if not throughout described in an unambivalent way (cf. the well-known Phil. 2), and the body-consciousness and use of body-metaphors for the church and so on (cf. further below). Or is it simply the love and grace of God for people that is the point of departure in the New Testament, and that any special consideration construed for human beings and human life in particular flows from this divine love? However, studying the texts of the New Testament, matters appear somewhat more complicated.

4 More than making sense of metaphors or reading them against the grain, contemporary interpreting communities also need "to choose the moment" in which to interpret them, e.g. choosing whether to align themselves with the authoritarian roles claimed by Paul or others, or that of dependency required of the communities addressed, but also whether the particular attitude accompanying the role is appropriate today (cf. Polaski 2005:80-81).

5 This paper will not dwell on the use of the Bible in moral discussions (cf. Good 2007; Punt 2005 etc.), or the question whether the connection between ancient texts and modern concerns should be attempted at all (cf. recently a novel response in Berlinerblau 2005), or other related questions.

6 Two important considerations are appropriate when tracing the (possible) relationship between modern(ist) concepts and ancient, normative texts, such as the Bible. First, while the anachronistic attempt to find our concerns in a simple and un-negotiated or immediate way acknowledged and reflected in the Bible is generally avoided, the further step of attempting to try and formulate what could have been an analogous concept or consciousness is not always engaged. Secondly, the use of the Bible in reflecting upon and construing "biblical" positions on contemporary concerns is a dangerous venture but probably one not possible to avoid in a context where the Bible is viewed as (at least) the charter or foundational document of communities of faith. "The Bible is seen to be a source that has given rise to values which are fundamentally to be associated with human rights, such as human dignity, freedom, justice and equality" (Vorster 2000:104). 


\section{The Bible on Human Dignity, or 'In-dignity'?}

A particular problem for our topic is that the Bible and the New Testament in particular makes more of the indignity, the unworthiness of humans and human life; promoting human dignity as such is not on the biblical agenda. A few texts such as Mt. 25 in the New Testament in the past were frequently employed to argue for the Bible having a favourable disposition towards notions such as human rights, human dignity, and the value of human life. However, such claims may in the end be too simplistic, and are also not borne out by biblical texts that generally stress both the vulnerable and almost brittle nature of human life, and along with mortality the propensity towards disobedience, violence, sin and the like. ${ }^{7}$

Many of the Old Testament themes on the precarious position of human beings, ontologically, existentially and relationally, ${ }^{8}$ function as the points of departure for the New Testament's authors. In the gospels it is the weak human beings who not only deliberately expose their selfish and undignified natures in inappropriate and unusual ways and when least expected, but they are often portrayed to do so in contrast with the example of Jesus. But the example of human life provided by Jesus is at least in the eyes of the spectators, friend and foe alike, hardly praised for its dignity; down to and exemplified in the cross (cf. Punt 2009a), humility, vulnerability and even shame rather than dignity describe the life of Jesus! In the earlier writings of someone such as Paul, the image presented of human beings is not only one of weakness and lack of dignity, but to some extent also of corruptibility (e.g. Rom 1 and 7). And in the General Epistles, human beings find themselves not only without dignity but even without a home, socially dislocated (1 Peter's 'aliens and exiles'), and having to reconfigure a (new) sense of identity. In these and other late New Testament writings, such as the Johannine materials, it is noteworthy that dignity is not only derived but also postponed: temporally (evident in Revelation; but, found already in Paul's apocalyptic), but even spatially to a different level of existence (as in the Fourth Gospel) (cf. Punt 2007:241-252).

\section{In-Dignity, or the Renunciation of Human Dignity?}

If such a cursory reading at least captures the broad sentiment, the position afforded to human beings in the New Testament is not one that is either premised upon or focused on human dignity. But (for our sensitivities) the problematic portrayal of human beings as unworthy and undignified, not only before God but also socially, ontologically and existentially, is exacerbated by the frequent moral exhortations in these texts not to insist upon their dignity and rights as human beings. Rather than a call upon people to claim and celebrate their dignity, the New Testament with different voices consistently insisted upon people's renunciation of their dignity.

Cf. Hanks' recent commentary on the NT in which he attempt to hear the voices of, amongst others, sexworkers (Hanks 2000).

8 In the Old Testament, the human being is presented in rather an ambivalent way. On the one hand, a human is described as created in the image of God (Gen 1; Ps 8), but on the other hand, the transitory nature of human life, and therefore of human existence itself, is generally emphasised. The Pentateuch's focus is clearly on human beings in so far as they exist and live in terms of the divine covenant - and careful not to generalise and oversimplify, it is mostly one particular group which remains in focus, namely the Israelites. Their story is not one generally characterised by dignity, nor do they exercise a claim to dignity. In the wisdom literature it is precisely the vulnerability of human life which is emphasised and which receives different possible responses: "Fear God" (Prov. 2:5; Eccl 12:13), as well as "Eat, drink, and be merry because tomorrow we die" (Prov. 9:7). Even the position that the prophetic literature holds human dignity as a basic consideration is to be subordinated to these texts' strong focus on divine justice as their primary point of departure. 
One of the clearest - even if not most often referred to - formulations of the insistence on the individual's renunciation of claims upon human dignity is found in 1 Cor. $6: 7 \mathrm{~b}$

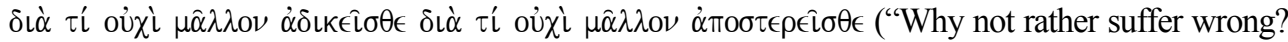
Why not rather be defrauded?" RSV). In a section in which Paul, with characteristic gusto and a good deal of sarcasm, discouraged law-suits among fellow believers, he castigates the

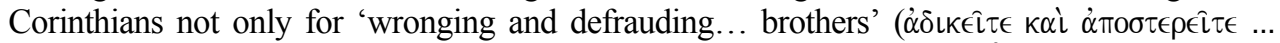
$\dot{\alpha} \delta \in \lambda \phi$ oús Cor. $6: 8)$ but also for not being willing to suffer wrong. ${ }^{9}$ The more familiar insistence on the need for self-denouncement of the rights and dignity by the disciples of Jesus is found in the Sermon of the Mount (Mt. 5-7; cf. Lk. 6:20-49). It reached its culmination in Jesus' insistence that his disciples should not exercise their rights in as far as they existed in the first-century context for people of their social location, but be willing to denounce their claims, culminating in the call that they should love their enemies (Mt. 5:3848).

What is clear, is that in the New Testament, the foundation for claims upon and instructtions for self-denouncement is found the example of Jesus (Phil. 2:5-8; 1 Pt. 2:23). Grounding the self-denouncing attitude in the words of Jesus is preceded in the New Testament by the understanding that the very life of Jesus was the example of a life of indignity rather than dignity, giving rather than receiving, forsaking rather than claiming. Importantly though, this was not simply about an individual or personal attitude of unselfishness or willingness to put the concerns of others before the own. More intensely, it is a call upon the marginalised to renounce human dignity, and to do so within in hierarchical society which offered no recourse to protective measures, which added up to making a divine appeal to and providing religious justification for the maintenance and exacerbation of the marginalised in their state of deprivation.

\section{Considerations: Social Locations and Conditions}

Lest the perception be created that the portrayals of human life in the New Testament texts are simply repugnant abstractions, best forgotten, or idiosyncratic rumblings at best, these texts' socio-historical context explain at least certain elements of the portrayals. An investigation of human dignity in the New Testament requires appreciation for the complex and multi-facetted way in which first-century people and their value or worth or dignity were in play in the first-century CE contexts, where honour and shame were often pivotal values within a hierarchical and patriarchal society; and, for an environment that was thoroughly saturated with the omnipresent and hugely influential Roman Empire on socio-political as well as economical and even religious levels.

A useful starting point for considering the New Testament texts' contributions to human dignity is to note the particular ways in which value was ascribed and inscribed. It particularly was the lack of dignity or even indignity that informed certain categories of people and the concomitant mechanisms society in general saw fit to employ in order to ensure the welfare, politically and divine, of society. It was in particular slaves; women; children; and, the 'Other' which at the time were regulated and handled through systems of slavery, patriarchy, hierarchy(-ies) and othering (including stereotyping; vilifying; exclusion; etc.). While space does not allow for full-length discussions of each of these categories and their structures and discourses of control, the following broad notions are vitally important for considering the contours of human dignity in New Testament texts.

Noticing that similar sentiments were expressed in Plato's Gorgias 509C, hasty conclusions about the New Testament's either superior or idiosyncratic moral code should be avoided (cf. Orr and Walther 1976:195). 


\section{The Imperial World of the Roman Empire in New Testament Times}

Amidst much talk of 'empire' and 'neo-colonisation' today, the impact of the Roman Empire, which built upon and furthered an already hierarchical society, on society and human lives human generally, and specifically on intentional communities such as the early communities of followers of Jesus, can hardly be fathomed. The omnipresent and omnipotent Roman Empire in its various forms and guises largely determined the materiality of life in the first-century Mediterranean context. First-century people had regular contact with the Empire through its visual images and verbal and written decrees, through its military presence and power, and its social systems such as patronage, all of which served to reinforce Roman imperial presence, as well as people's submissiveness to it. The all pervasive Roman imperial presence and practice informed the consciousness and worldview of people around the Mediterranean in the first century CE; its material and historical imperialism, as well as discursive imperialism informed, sculpted and determined the daily lives of people in a myriad of ways, also at the level of consciousness, in terms of ideology.

The Roman Empire existed by virtue of a number of mechanisms and structures, as well as some more intangible rhetoric, which propped up the former. Military conquest, the system of patronage, the rhetoric of peace, ${ }^{10}$ prosperity and concord, and the imperial cult (cf. also Horsley 1997:87-90; 2000:74-82) made possible what is today described as the Roman Empire. Its pervasive influence was, however, probably strongest at ideological level, ${ }^{11}$ where it interconnected with various dimensions of first-century life across the spectrum of communities spread out geographically. ${ }^{12}$ It was the rhetoric of Empire that inscribed and replicated the language of power and domination after military conquest, and which was required for Rome's position of power - the materiality of Empire and imperial ideology fed of one another.

\section{Hierarchical, Patriarchal Society}

First-century society was hierarchical and patriarchal which meant the understanding and regulation of human life according to specific understandings of power and control, was structured according to set-categories and social locations and roles, determined by social status, and with a clear male-gender bias. All of this had particularly limiting implications for the lives of the marginalised, which in this context were slaves, women, children and various other categories of 'others' (such as strangers, physically handicapped people, those suffering from chronic illness and disease, freed persons, and so on). "In Mediterranean societies of the past ... there was not the faintest trace of human equality, whether before the law of even in some ideal equality of all males" (Malina 1993b:134). The most identifiable marginalised group, because of its sheer size but also due to its prominence

10 Concepts such as peace was of course filled out differently by those from within and without the Empire; Tacitus puts the following words in the mouth of the British rebel commander Calgucus about the Romans: "To robbery, butchery and rapine, they give the name of 'government'; they create a desolation and call it "peace"" (in Hollingshead 1998:26 n16).

11 An empire is generally driven by a sense of moral virtue, and operates with a vision of re-ordering the world's power relations for the sake and betterment of all.

12 The widespread, insidious presence of Empire in NT texts gives rise to questions of culture, ideology and power, as suggested by Segovia (1998:57-58): "How do the margins look at the 'world' - a world dominated by the reality of empire - and fashion life in such a world? How does the center regard and treat the margins in light of its own view of the 'world' and life in that world? What images and representations of the otherworld arise from either side? How is history conceived and constructed by both sides? How is the 'other' regarded and represented? What conceptions of oppression and justice are to be found?" 
through its oblique presence and its members (slaves) existence through its denial, being denied beings ('natal alienation', Patterson), was probably slaves.

Institutionalised slavery and its pervasive character had considerable impact on the character of the inhabitants of the Greco-Roman world, informed by the owner-slave relationship and the accompanying distribution of power throughout society (cf. Patterson 1982:35). Characters and habits were moulded by lifetimes of command and obedience in a slaveholding society, where young and old became habituated to power. ${ }^{13}$ The impact of a slaveholding society is evident among New Testament authors, who both presupposed the presence of slavery and its moral acceptability; ${ }^{14}$ to the extent of emphasising submissive conduct of slaves towards the authority of slaveholders as a function of appropriate Christian life. ${ }^{15}$

The other rather obvious difference pertaining to first-century society would be the impact of its nature as also a patriarchal society, which through its structural and ideological patterns and conventions prescribed not only specific gender roles but also a decidedly superior position to men above women. Patriarchal notions were religiously defined and justified, a natural order and natural laws believed to reflect God's design for the universe (Isherwood and Stuart 1998:20). The male body was constituted in opposition to that of the woman, the child or the slave ${ }^{16}$ and thus defined by mastery, in the first place of the self but also in exercising authority and control over others. ${ }^{17}$ Freeborn men were trained to resist servility, to further their own power. The situation started to change in the first century with some women who through inheritance assembled great wealth and together with it power and influence, and with increasing liberalisation of women's participation in public life. It is nevertheless unlikely that women were simply included when men were addressed or male categories were invoked by New Testament authors, or that prescriptions and proscriptions for men were immediately and equally transferable to women.

13 As happened in later societies; closer to home, cf. Giliomee (2004:157-158) on how the early Afrikaners of the early nineteenth century were influenced by slavery to the extent that they both tyrannised their own slaves but appeared to have buckled under the pressure of those they considered having authority over them.

14 Claims that Jesus' teaching about the dignity of all people in the end destabilised the dehumanisation of slaves evidently ignores the importance of the trope of slavery in his teachings (cf. Glancy 2006:145). Another difficulty is also knowing when a narrative is in fact having a slave in mind, cf. the two accounts of the Roman military official in Mt. 8:5-13 and Lk. 7:1-10 and the uncertainty whether the afflicted person is a child or slave.

15 While Col. 3:22-25 and Eph. 6:5-9 addressed both slaveholders and slaves, indicating responsibilities and obligations and ostensibly (and at best) to maintain the stability of the household through treating the slaves fairly, in 1 Pt. 2:18-21 slaves are instructed to submit even to excessive and abusive authority (Punt 2009a).

16 The bodies of slave and child were often conflated, as hinted in the Greek word pais which could refer to both; and also in terminology that referred to [male] slaves as boys; and since male slaves' paternity were not legally recognised. The perception of slaves and servants as immature and effectively being like children, and referred to as "boys" and "girls" was found in among others the racially segregated USA and Apartheid SA!

17 The patriarchal cornerstone at the time was the family, with the legal authority vested in the paterfamilias, extending his power over wife, children, slaves, animals and land. The power and authority vested in the paterfamilias was reflected and expanded in the social and political, military and religious, and others forms of public power wielded by the ruling elite, while excluding women from higher education, elite professions and military and political leadership. Cultic roles occupied by women in the Graeco-Roman world were restricted to the female sphere, while Second Temple Judaism excluded women from priesthood and the inner sanctuary of the temple through purity laws. However, the relative openness to forms of women leadership in early Christianity is probably indicative of some flux in gender roles in first-century societies. 


\section{Patronage and Benefaction}

In the first century CE the system of patronage was widespread, ingrained, and saturated the whole known world. Patronage relied on the notion of justice being served through a form of generalised reciprocity along the lines found in kinship structures. Economic, political or religious institutional relationships in particular were arranged according to an overarching characteristic of kinship or family feeling through the social, institutional arrangement of patron-client relationships (Malina 1993b:133-137). The importance of the patronage system must be considered within the context of the Emperor as ultimate patron, who was seen to devolve his power down to other patrons, each with circle of influence as well as group of underling-patrons, continuing in a never-ending extension of the patronage system. ${ }^{18}$ In these unequal relationships, patrons naturally claimed and received much higher status, as well as power and resources than their clients.

\section{Pivotal Social Values of Collectivist Communities: Honour and Shame}

The first-century Mediterranean world was populated by a broad diversity of societies, yet strongly collectivist in nature and the pivotal social values of honour and shame functioned primarily as group value. Honour and shame ${ }^{19}$ were the core values of the time, even if the construal and regulation of these values has been more diverse than is often admitted (cf. Osiek and MacDonald 2006:7-9). As gendered values in a male dominated world (Malina 1993a:28-62), honour was associated with men, implying strength, courage, daring, valour, generosity and wisdom, while shame was ascribed to women in the form of privacy, reserve and purity.

The proposal that honour was the first-century equivalent for human dignity (West 2009) is problematic in a number of ways. Most importantly, in antiquity honour was both bestowed and constantly striven for in highly agonistic society whereas contemporary notions of human dignity construct it as a human right and thus inherent to people (even if constantly constructed thus), entailing the equality of all people regardless of race, class, gender, sexual orientation, age or any other category of distinction. Another important difference between ancient honour and shame and modern-day human dignity, is that in the case of the former, honour was defined by the ruling class or elite while modern human rights is also and at times explicitly aimed at and claimed by the marginalised and the excluded of society. A third very important difference would be situated in the gendered nature of honour and shame values, which would generally exclude women from laying claim to honour but to honourable shame at best, unlike the concern with women's and lesbigays' concerns with regard to dignity.

In the end, one way of approaching the theme of human dignity in the New Testament could thus be to track all the instances where the conventional values and structures of the time were challenged, subverted and transposed by Jesus, the apostles and other early followers of Jesus. ${ }^{20}$ However, some of these instances would take us back to in-dignity and the renunciation of dignity; on the other hand, and as emphasised throughout this contri-

18 "Far from trying to eradicate traditional patronage relationships, emperors encouraged their continuation, in part because they were the main mechanism for recruitment of new members of the imperial elite" (Garnsey and Saller 1987:201; Chow 1997).

19 Shame was as the opposite of honour a claim to worth that was publically denied or repudiated; however, while being shamed was negative as in the sense of being stripped or reduced in honour, having shame was a positive value, implying concern over some-one's honour (Plevnik 1993:96).

20 E.g. in terms of honour and shame, cf. Mk 9:48, 10:44; Mt. 20:27, 23:8-10; Lk. 14:7-11, 22:26. 
bution, notions related to human dignity and rights in the New Testament were thoroughly enmeshed within the first-century concerns related to human existence, complete with sentiments and categories as discussed above. Nevertheless, and without compromising the ideological-critical angle, a more constructive exploring of specific themes or concepts of human dignity in the texts of the New Testament, for how they may inform and interact with modern, theological perspective may in the long run be more profitable. In what follows, first steps are taken on this road.

\section{Concepts: The Potential of Some New Testament Themes}

A range of considerations, themes and concepts found in the New Testament, some of which are invoked in theological discussions on human dignity, but others whose potential in this regard has perhaps not been adequately recognised, can briefly be identified and considered for their eventual contribution, mostly constructive, to considerations of human dignity in biblical and theological discourse. Given obvious constraints, the focus here will be on two aspects, the incarnation of Jesus Christ and anthropology - a series of concerns, all of them closely connected to incarnation.

\section{Incarnation}

The incarnation of God in Christ evidently played an important role in the New Testament documents. Despite the often-remarked upon absence of biographical depictions of Jesus in his letters, the notion of the embodied Jesus Christ was a central concern even for Paul (cf. Punt 2009d). While one of the clearest affirmations of the incarnation and all it implied is found in the well-known Johannine prologue (Jn. 1:1-18), its importance and implications form a golden thread running through the New Testament, albeit with different emphases. From a focus in the Johannine materials on God that became human to Jesus as image of God in the Pauline letters (e.g. Phil. 2), Hebrews (e.g. Heb. 1) and the Johannine letters (espec $1 \mathrm{Jn}$.), the incarnation forms the starting point for much of the reasoning found among New Testament authors.

Creation, its goodness (as in the Gospels) and concern about it (e.g. Rom 8), is not unimportant to New Testament authors. However, Paul set the pace with shifting focus to the re-creation, the new creation ${ }^{21}$ (Gal. 6:15; 2 Cor. 5:17) wrought by Christ as the central concept (Stowers 1998:304). Furthermore, the Philemon-letter ${ }^{22}$ is in the Pauline corpus at the beginning of a process and therefore part of a larger reality where it increasingly became questionable to treat fellow-believers differently because of status concerns - admittedly, amidst the presupposition of a particular eschatological framework. However, and without the often idealised portrayal of humans understood in modern, individualised terms of autonomous individuals, the urge towards unity within the ekklesiai was still cast in hierarchical terms (Stowers 1998:303-304; cf. Punt 2009b).

21 Rather than "the recognition of the dignity of humankind in terms of creation" (Marshall 1993:190), Paul found his starting point in the incarnation, that issues in the new creation.

22 When sentiments about dignity, together with the claim that slave ownership is incompatible with faith in Christ, is seen by some to be the reason for Philemon's inclusion in the canon (e.g. Marshall 1993:191), one may, perhaps rather cynically, wonder why it took another 1800 years before slavery was abolished? $\mathrm{cf}$. Barclay (1997:119-126) for a brief reception history of the letter in Christian theological tradition and attempts to claim it as a 'prelude' to the emancipation of slaves. 


\section{New Testament Anthropology}

It is understandable that the focus on the incarnation would have had important implications for the understanding of human corporeality, personhood and identity, and that these would have impacted on theological formulations in the New Testament - these contours can briefly be sketched out as follows.

\section{- Corporeality (or, Bodiliness)}

Understanding the first century CE body amounts to more than unsophisticated oversimplifications framed in modernist thinking informed by the biological sciences (e.g. Martin 1995:3-37), and it requires more than simply distinguishing between Semitic and Greco-Roman views, ${ }^{23}$ particularly since the New Testament authors showed strong allegiance to a Jewish heritage while living in an, at the time, increasingly Hellenised world. This formed the setting for the position on the human body in the New Testament that was (at best) ambiguous, with on the one hand its undeniable and non-negotiable importance in light of Christ's incarnation and resurrection (cf. 1 Cor. 15), and the notion of a general resurrection, yet on the other hand, its relative unimportance given what lies beyond the body. What is clear in the New Testament is the relative importance of understanding bodiliness or corporeality (incl. gender and 'sexuality') (cf. Punt 2005; 2009b) for constructing an adequate portrait of human value and worth - for understanding the human being as an embodied person.

\section{- Personhood in the New Testament}

The New Testament texts offered no clearly defined concept of personhood: different criteria applied for what constituted a person, and went beyond the modern perception of human beings as embodied psyches and therefore persons (Berger 2003:26-29). New Testament notions of being a human being and resulting boundaries are best plotted on the firstcentury map of identity-concerns, which were influenced by dyadism, or an other-directed orientation (Neyrey 1993:49-52). People were known and valued in terms of their dyad, the people or elements that defined them. As group-oriented, collectivist people in a non-introspective culture, the in-group provided the means by which people understood themselves and others (Malina and Neyrey 1996:122). The strong sense of and efforts to maintain identity in a collectivist culture, required demarcation, as well as identification. It was at least as important to define a group over against or in terms of other groups as was the concern with self-identity (and reflection upon it) (Malina and Neyrey 1996:122). But the construction of borders between people, us-and-them binaries, was within the first-century, agonistic society not seen as complimentary, ${ }^{24}$ as the New Testament documents attest.

23 First-century thinking about the human body was more complex than a simple separation between different elements such as body and soul, or ranking them in a hierarchy of values. The typical difference between the Jewish and Greek understandings of body entailed the presentation of body and soul (nepeš) as unity, indissoluble to the point of ceasing to exist at death, which contrasted with the prevailing Greco-Roman view that the mortal body could be understood apart from the immortal soul (psychē). The body in fact was often understood by those in the Greco-Roman world to have imprisoned the soul, and that the soul is freed from its trapped existence at death at which point it then ascends to heaven (Bassler 2007:87) or journeys to the underworld.

24 Hostility and even violence was natural in the first-century Mediterranean context (Botha 2000:8-18), with different forms of aggression common and part of daily life, evident from even a brief analysis of New Testament vocabulary. 


\section{- Reformulating Identity}

The early followers of Jesus engaged in a revolutionary kind of 'oral literacy', showing independence and originality in their use of culture and tradition, in order to formulate a new identity. ${ }^{25}$ Their focus was on imitatio Jesus rather than submission to the Torah or another canon, and when by the second century the use of codices became characteristic in Christianity, the focus of this practice was on its practical rather than cultic use (Stroumsa 2003:153-173). While the Jesus followers inhabited a world populated by a variety of oral traditions and cultures including those from the Jewish context, they increasingly carved out a language and an ethos which incorporated beliefs about Jesus Christ, ${ }^{26}$ formatting a social world where they constructed a new identity. They used words and information that created reality as basis for the new social environment and relations they devised (Lampe 1995:940). ${ }^{27}$ However, identity issues were generally perilous and fraught with danger, as reflected in for example Paul's fluctuating fortunes in the Corinthian correspondence that stretched over a few years' interaction between the apostle and the community.

\section{- Pauline Body Theology}

In what remains for many a surprising place to locate such sentiments, Paul's letters evidence a cosmic-sensitive view, which stands in close relation to his human ethics (cf. Polaski 2005:81). Paul's cosmic worldview related not only to all of humankind in broad generalising terms, but showed his concern with the materiality of the created world (Rom 8). Such concern was not generally the norm in a context characterised by materialist pessimism and, at best, a sense of distrust towards the materiality of human existence. However, as argued above, the world and the materiality of existence including human life received a new character in the light of the incarnation of Christ. In a Pauline body theology, a new epistemology of body is signalled in the sense that the contextual nature of the body is taken seriously, but also that the body is understood as a site of revelation. On the one hand, the use of body as metaphor shows the importance of bodiliness in Pauline thought, and for the importance of body theology. On the other, it can, however, be asked to what extent Paul's metaphorical use of the body ${ }^{28}$ carried within itself the seeds of the neglect and disavowal of the real-life body in later Christian tradition?

Although the distinction between Hellenistic (or rather Diaspora) and Palestinian Judaism is tenuous at best, the discoveries of the scrolls in the Qumran caves have shed some new light on what was taken to be Pauline neologisms or Hellenistic derivatives, of which

25 The notion of "identity" is today mostly perceived as a modern personalist construction, including not only psychological but also somatic and social experience; however, in postmodern thought identity is "not static, essential and clearly defined" but "a fluid, shifting perspective, which is generally context-dependent" (Tolbert 1995:310). A deterministic appropriation of first century notions of identity such as assuming a monolithic or homogenous constitution within groups must be avoided, since the in-group boundaries were often uneven and of differing qualities.

26 For the moment, leaving aside the question of how such an identity was created, although the (re)interpretation of the scriptures of Israel was clearly an important element in the process.

27 Methodologically, the dangerous simplification often found in identity politics - where identity is not about persons or institutions, but ideological subject-positions reflecting social interests and reproducing relations of oppression - requires a shift from identity to identification (cf. Stokes 1998:736,744) or identifying. Identity is situated in ideology rather than substance.

28 Other aspects related to Paul's invocation of the body as metaphor cannot be addressed here; e.g. Banks (1994:67-76) also shows how Paul's use of the body metaphor focused on growth and maturity; even faith was connected to the body and its maturity as in the milk-metaphor (1 Cor. 3:1; cf. Heb. 5:13 vs. 1 Pt. 2:22) Knowledge stood central for Paul in as far as the body was concerned, and he uses different terminology to express it. 
the sources were still to be determined. Subsequent to the Qumran discoveries, phases such

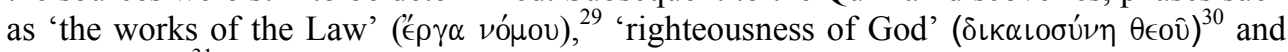
'sinful flesh' ${ }^{, 31}$ no longer have to be understood as Pauline idiosyncrasies. The Hebrew Bible's references to flesh amounts to a emphasis on weakness and mortality, and the ascription of $\sin$ and rebellion to flesh or bodily existence is a later development, of which traces are found in the Qumran scrolls. ${ }^{32}$ The close parallel to Paul's contrast between 'flesh' $(\sigma \alpha ́ \rho \xi)$ and 'spirit' $(\pi \nu \in \hat{u} \mu \alpha)$ as in Gal 5:17 or Rom 8:5-8 is found in the characterisation of 'flesh' (בשר) in 1 QS $11.9,12^{33}$ with sin and rebellion, even amounting to a power that provokes and causes evil deeds. The earlier adduced parallels from Hellenistic Judaism such as the use of 'body' $(\sigma \hat{\omega} \mu \alpha)$ and 'flesh' ( $\sigma \alpha \dot{\alpha} \rho)$ ) to refer to the earthly sphere, still left the Pauline association of the body with the reason or occasion for sin, unexplained - a hiatus that Qumran fills (Frey 2003:105; cf. Jewett 1971:92).

Finally, how does one deal with these and many other themes not mentioned here, given the wide-ranging apocalyptic perspective(s) of the New Testament texts, anticipating 'regime change'? How should the emphasis on adjustments and change be construed in a context that to a large extent expected the radical change of all that existed, that anticipated an alternative society or better, reality? And while some texts (particularly the Pauline epistles) generally posit a call for contemporary change in view of the anticipated future changes, to live different now because of the upcoming changes of the future, others (deutero-Pauline epistles, Johannine materials, general epistles and Hebrews) offer suggestions, both theologically and socio-culturally informed, on how early Christian communities were to fit into late first-century or early second century society!

\section{Conclusion}

As LaFleur argues about the body and its possible genetically inheritable malleation, "Here is an area in which we should be monitoring instances of cruelty rather than becoming preoccupied with some idea of the natural" (1998:52), human dignity and human rights is first and foremost about socially located people rather than some abstractions. In the context of our seminar, it is important to acknowledge and seek to reverse the damage done by churches' Bible-based oppressive and uncritical collusion, ${ }^{34}$ over many centuries, in for

29 Significant Qumran parallels would include the early Essene halakhic work, 4QMMT 14-17, ii, $2 \mathrm{f}$ where the phrase "precepts of the Torah" (מעשי התורה) is used, referring to a Palestinian Jewish discussion on deed prescribed by the Law (cf Frey 2003:104-105).

30 While this expression is not found as such in the Old Testament / Hebrew Bible, although the concept of "righteousness" is often used, Qumran shows it to be a proper Jewish Palestinian phrase (cf 1QM 4.6; 1QS $10.25,11.12)$; other parallels are also found such as Paul's use of "sons of light" and "sons of day" (1 Th 5:5) being matched with the use of "sons of light" as opposed to "sons of darkness" in 1 QS 1.9-11, not to mention Paul's use of "works of darkness" in Rom 13:12 (cf Frey 2003:104).

31 "When Paul uses the term 'flesh', this should not be understood from Hellenistic thought with its dualism of body and soul and from the negative view of the bodily existence but rather from the Biblical and postBiblical sapiential traditions in which the strife of human beings was seen as inclined towards evil and hostile against God's will”' (Frey 2003:109).

32 In the concluding hymn of the Rule of the Community, reference is made both to the "assembly of unfaithful flesh" (בשר- עול; 1 QS 11.9-10) and also to the "sin of the flesh" (שעין בשר; 1 QS 11.11-15).

33 Even in the scrolls from Cave 4, generally seen as less sectarian, similar notions about a "fleshly spirit" and the association of flesh with "everything that God hates" is found in documents such as 4QInstruction and the Book of Mysteries where "flesh" is used with the notion of sin or hostility against God (Frey 2003:107).

34 "The Bible enabled the gradual development of those very values which to this present day provide Europe with a basis for democratic consciousness ... and also lay the foundations for a code of human rights" (Lee and Arapović 2001:378, quoting Drnovšek, Prime Minister of the Republic of Slovenia in 1996; emphasis added). 
example their complicity in and propagating of slavery; their involvement in sanctioning racial prejudice and discrimination on biblical grounds (e.g. Combrink 1986); their endorsement of patriarchal, sexist and marginalising versions of family life (Barton 1996:451-462); and, of promoting a particular idea of marriage to the benefit of men and certain economic positions (e.g. Ellison 1996). This raises many questions as to how to unsettle such fixed socio-political and socio-economic patterns and theological rationale and justification, about the place and role of the (continuing) use of the Bible in such thinking, and on finding an alternative theological grammar and vocabulary to address human dignity in attending to issues of humanity and body, gender and sexuality, family life and children, in the various, overlapping spheres of modern life?

Discussions on human dignity and the New Testament can never divest itself from situating and understanding the concept within its appropriate first-century context with all that it entails. But the New Testament also allows for further suggestive, imaginative appropriations of human dignity, stimulating thinking about its possible deployment in a modern context where human dignity is understood vastly different from first century norms and conventions about human beings and their value.

The texts of the New Testament make it clear that as far as (at least, certain) human beings indeed have it, their dignity is derived from God, initiated and enabled through the incarnated Son of God - while at the same formulated within and according to the constraints and vicissitudes of the reigning socio-historical context. When these texts are used as starting point, modernist claims about the inherent dignity and quality of human life based on biblical texts have to be carefully considered in both the absence of as well as (at best) the qualified notions of value ascribed to certain people such as slaves, women, children and the Other. Human dignity in the New Testament in the sense of the value or worth of being human is enmeshed in a range of otherness, interests, convictions and concerns. It is a notion that has to be described and understood as relational, but also as structural and most definitely as construed or constructed concept. Eventual claims about the derived or attributed dignity of human life never became absolute within the New Testament, but remained relational, and functioned primarily in terms of God's perceived justice, and of course, in relation to the incarnation and ministry of Jesus. But is this not wherein, perhaps, lies the potential positive use of New Testament texts in discussions on human dignity and rights for today?

\section{BIBLIOGRAPHY}

Banks, R 1994. Paul's idea of community. (Rev. ed.) Peabody: Hendrickson.

Barclay, JMG 1997 Colossians and Philemon. New Testament Guides. Sheffield: Sheffield Academic Press.

Bassler, JM 2007. Navigating Paul. An Introduction to Key Theological Concepts. Louisville, London: Westminster John Knox.

Berger, K 2003. Identity and Experience in the New Testament, trans. C Muenchow. Minneapolis: Fortress.

Berlinerblau, J 2005. The Secular Bible. Why Nonbelievers Must Take Religion Seriously. Cambridge: Cambridge University Press.

Black, CC 2006. God's Promise for Humanity in the New Testament. In God and Human Dignity, (eds.) RK Soulen, and L Woodhead, 179-95. Grand Rapids: Eerdmans. 
Botha, PJJ 2000. Submission and Violence: Exploring Gender Relations in the FirstCentury World. Neotestamentica 34(1):1-38.

Combrink, HJB 1986. Perspektiewe Uit Die Skrif. In Die NG Kerk En Apartheid, (ed.) J Kinghorn, 211-34. Braamfontein: MacMillan.

Crook, ZA 2004. BTB Readers Guide: Loyalty. Biblical Theology Bulletin 34(4):167-77.

Elliott, N 2008. The Arrogance of Nations. Reading Romans in the Shadow of Empire. Paul in Critical Contexts. Minneapolis: Fortress.

Ellison, MM 1996. Erotic Justice. A Liberating Ethic of Sexuality. Louisville: Westminster John Knox.

Engberg-Pedersen, T 2005. The Relationship with Others: Similarities and Differences Between Paul and Stoicism. Zeitschrift für die neutestamentliche Wissenschaft 96(1-2):35-60.

Frey, J. 2003. The Relevance of the Dead Sea Scrolls for New Testament Interpretation with a Bibliographical Index. Acta Theologica 23(2):86-116.

Garnsey, P and R Saller 1987. The Roman Empire. Economy, Society and Culture. London: Duckworth.

Giliomee, H 2004. Die Afrikaners. 'n Biografie. Kaapstad: Tafelberg.

Good, DJ 2007. "Wrestling Biblically with the Changing Shape of the Family." [cited 17 May 2007]. Available from http://www.ekklesia.co.uk/node/4844/print

Hollingshead, JR 1998. The Household of Caesar and the Body of Christ. A Political Interpretation of the Letters from Paul. Lanham: University Press of America.

Horsley, RA. 19971 Corinthians: A Case Study of Paul's Assembly As an Alternative Society. In Paul and Empire. Religion and Power in Roman Imperial Society, (ed.) RA Horsley, 242-52. Harrisville: Trinity Press International.

Horsley, RA 2000. Rhetoric and Empire - and 1 Corinthians. In Paul and Politics. Ekklesia, Israel, Imperium, Interpretation. Essays in Honor of Krister Stendahl, (ed.) RA Horsley, 72-102. Harrisville: Trinity Press International.

Isherwood, L and E Stuart 1998. Introducing Body Theology. Introductions in Feminist Theology. Cleveland: Pilgrim.

Jewett, R 1971. Paul's Anthropological Terms. A Study of Their Use in Context Settings. AGJU, vol. 10. Leiden: Brill.

LaFleur, WR 1998. Body. In Critical Terms for Religious Studies, ed. MC Taylor, 36-54. Chicago: University of Chicago Press.

Lampe, P 1995. Identification with Christ. A Psychological View of Pauline Theology. In Texts and Contexts. Biblical Texts in their Textual and Situational Contexts. Essays in Honor of Lars Hartman, eds. T Fornberg and D Hellholm, 930-943. Oslo: Scandinavian University Press.

Lategan, BC 1989. Intertextuality and Social Transformation. Some Implications of the Family Concept in New Testament Texts. In Intertextuality in Biblical Writings. Essays in Honour of Bas Van Iersel., (ed.) S Draisma, 105-16. Kampen: JH Kok.

Lee NC and B Arapović 2001. The Bible in political context. New republics from old Yugoslavia and the former Soviet Union. Interpretation 55(4):378-388.

Malina, BJ 1993a. The New Testament World. Insights from Cultural Anthropology. (Rev ed.) Louisville: Westminster/John Knox Press. 
Malina, BJ 1993b. Patronage. In Biblical Social Values and Their Meaning. A Handbook, (eds.) JJ Pilch and BJ Malina, 133-7. Peabody: Hendrickson.

Malina, BJ and Neyrey, JH 1996. Portraits of Paul: An Archaeology of Ancient Personality. Louisville: Westminster John Knox.

Marshall, IH 1993. The Gospel and Slavery in The Theology of the Shorter Pauline Epistles. Donfried, KP and Marshall, IH (eds.). New Testament Theology. Cambridge: Cambridge University Press, 171-191.

Martin, DB 1995. The Corinthian Body. New Haven and London: Yale University Press.

McFarland, I 2001. Personhood and the Problem of the Other. Scottish Journal of Theology 54(2):204-20.

Neyrey, JH 1993. Dyadism. In Biblical social values and their meaning. A handbook, (eds.) JJ Pilch and BJ Malina, 49-52. Peabody: Hendrickson.

Orr, WF and JA Walther 1976. 1 Corinthians. A New Translation. Introduction with a Study of the Life of Paul, Notes, and Commentary. The Anchor Bible, vol. 32. New York: Doubleday.

Osiek, C and MY MacDonald, with JH Tulloch 2006. A Woman's Place. House Churches in Earliest Christianity. Minneapolis: Fortress.

Patterson, O 1982. Slavery and Social Death: A Comparative Study. Cambridge, MA: Harvard University Press.

Plevnik, J 1993. Honor/Shame. In Biblical Social Values and Their Meaning. A Handbook, (eds.) JJ Pilch and BJ Malina, 95-104. Peabody: Hendrickson.

Polaski, SH 2005. A Feminist Introduction to Paul. St Louis: Chalice.

Punt, J 2005. Morality and body theology in Paul. Neotestamentica 39(2):359-388.

Punt, J 2007. The dignity of human sexuality: Compromised sexual selves and violated orientations. Scriptura 95:241-252.

Punt, J 2008. Biblical hermeneutics, actualisation, and marginality in the new South Africa. In African and European Readers of the Bible in Dialogue. In Quest of a shared Meaning, 387-405. Studies or Religion in Africa: Supplements to the Journal of Religion in Africa, vol 32. Leiden, Boston: Brill. (ISBN 9789004166561).

Punt, J 2009a. Cross-purposes? Violence of the cross, Galatians, and human dignity. Scriptura 102:446-462.

Punt, J 2009b. Paul, power and Philemon. A postcolonial reading. (forthcoming).

Punt, J 2009c. "Pauline bodies and South African bodies. Body, power and biblical hermeneutics". (JTSA, forthcoming).

Punt, J 2009d. The Aqedah in the New Testament. Considering sacrifice, violence and human dignity. Scriptura 102:430-445.

Segovia, FF 1998. Biblical Criticism and Postcolonial Studies: Towards a Postcolonial Optic. In The Postcolonial Bible, ed. RS Sugirtharajah, 49-65. The Bible and Postcolonialism, vol. 1. Sheffield: Sheffield Academic Press.

Stokes, M 1998. Someone's in the Garden with Eve: Race, Religion, and the American fall. American Quarterly 50(4):718-744.

Stowers, SK 1998. Paul and Slavery: A Response in Slavery in Text and Intepretation. Callahan, AD, Horsley, RA and A Smith (eds). Semeia, vol. 83/84. Atlanta: SBL, 291-293. 
Stroumsa, GH 2003. Early Christianity - a Religion of the Book? In Homer, the Bible, and Beyond. Literary and Religious Canons in the Ancient World, (eds.) M Finkelberg, and GH Stroumsa, 153-73. Jerusalem Studies in Religion and Culture, vol. 2. Leiden: Brill.

Tolbert, MA 1995. Afterwords. The Politics and Poetics of Location. In Reading from this Place. Vol.1: Social Location and Biblical Interpretation in the United States, (eds.) Segovia, FF and MA Tolbert, 305-317. Minneapolis: Fortress.

Vorster, JN 2000. (E)mpersonating the bodies of Early Christianity. Neotestamentica 34(1):103-124. 